\title{
\#RepealedThe8th:Translating Travesty, Global Conversation, and the Irish Abortion Referendum
}

\author{
Ruth Fletcher ${ }^{1}$ \\ Published online: 18 December 2018 \\ (c) Springer Nature B.V. 2018
}

\begin{abstract}
Why does \#RepealedThe8th matter for feminist legal studies? The answers seem obvious in one sense. Feminism has long constituted itself through the struggle for sexual and reproductive justice, and Irish feminism has contributed a significant 'legal win' with the landslide vote of approval for lifting abortion restrictions in the referendum on the 25th May 2018. That win comes at a global moment when populist legal engagement is doing significant damage in countries that regard themselves as world leaders, and beyond. \#RepealedThe8th offers Ireland, and the world, the actuality that the popular vote, and everything that contributes to it, could be something else. Repeal shows how legal tools like the vote may be made into an expression of care for reproductive lives. This expression is important in recognizing pregnant people as knowing agents who are best placed to decide, and in seeking to do justice to those who contribute to everyday reproductive life. But repeal, like the many who brought it into being, has multiple meanings. \#RepealedThe8th matters because it is a moving process of sociolegal translation, which draws on a collective energy, 'repeal energy', to turn the travesty that was the Eighth Amendment and all it represents into a search for the rest of reproductive life. In opening up the meaning of the vote, much like feminists elsewhere have opened up the meaning of the strike, Irish feminists have turned public mourning over past mistreatment into a series of reproductive connections. This is not a strategy that can be rolled out. Figuring out \#RepealedThe8th will take many tellings. Rather we need to give repeal, and repealers, room to breathe and rest. We need to feel our way through repeal's production of legal change so that this success is not reduced to some generic transferable set of legal instructions. I begin by reflecting on repeal as a process of feminist socio-legal translation, which shows us how legal change comes about through the motivation of collective joy, the mourning of damaged and lost lives, the sharing of legal knowledge, and the claiming of the rest of reproductive life.
\end{abstract}

Keywords Translation $\cdot$ Feminism $\cdot$ Legal activism $\cdot$ Reproductive Justice $\cdot$ Social reproduction $\cdot$ Social movements $\cdot$ Abortion $\cdot$ Constitutionalism

Ruth Fletcher

r.fletcher@qmul.ac.uk

1 Queen Mary University of London, London, UK 


\section{Introduction}

I felt the mood lift the day before. I was doing a bit of canvassing with one of the Together for Yes ${ }^{1}$ groups, and we went to take back the bridge. The Irish Centre for Bioethical Reform ${ }^{2}$ had been seen on the bridge earlier with their blown-up, distorted posters of foetal remains. So the TfY group wanted to open the space that ICBR had closed, and fill it with TfY paraphernalia and people. There was no sign of ICBR when we arrived, but the urge to make the bridge a temporary TfY zone was strong in any case. That morning's canvass had been the last one before the referendum vote the next day on Friday 25th May. Most of the people there had been organising and canvassing for removal of the Eighth Amendment over weeks, months, and years. They were happy, if tired and anxious, to get to this moment, to be nearing the day when the public would vote on the removal of a constitutional provision which equated the life of a pregnant woman with the life of her foetus, and prevented the legalization of abortion. In that most ordinary of ways, we took up positions on different sides of the bridge, displaying our repeal badges, sweaters and t-shirts, and waving home-made and official 'Vote Yes' signs at passers-by. As the minutes passed, it became clear that most of the cars driving beside or beneath us were honking or waving back in support. Various drivers, passengers and pedestrians did not react, and there were some definite thumbs down. But the enthusiasm of many of the responders was clear. Passers-by thanked us for everything we'd done to make the referendum happen. Maybe this was it. Maybe we were allowed to be happy.

Not the kind of 'happy' that wears with superficial promise, but the kind of happy that comes from knowing shared struggle together, from licking each other's wounds, from taking mutual pleasure in being contrary with travesty. ${ }^{3}$ Not the kind of 'allowed' that vests all authority in the one who would allow, but the kind that is an atmosphere which holds you together as you do what you can to make life better. And not the kind of 'we' that agrees who we are, but a 'we' that warms each other in differentiation and disagreement. We have had 35 years of the travesty of the Eighth Amendment and its humiliation of

\footnotetext{
${ }^{1}$ For more information on Together for Yes (TfY and \#Together4Yes), the civic campaign group which led the campaign for repeal in the immediate run up to the referendum, see https://www.togetherforyes. ie. Accessed 29 October 2018.

2 The Irish Centre for Bioethical Research (ICBR) is the Irish branch of the transnational anti-abortion activist organization Center for Bioethical Reform. I am not going to provide a link to the ICBR website, it is easy to find if you are interested. See McGuinness (2015) for one account of the 'guerrilla strategies' of transnational anti-abortion activism. One series of joyful moments during the campaign was generated by Radical Queers Resist as they responded to calls that ICBR were present, and used Pride flags to block the distressing graphic images which ICBR used; see further Donohue (2018).

3 Ahmed (2010) and Berlant (2011) have shown us how 'the promise of happiness' can be worked into a 'cruel optimism', so that the drive for happiness exhausts and obstructs. But happiness has multiples. Segal's account of Radical Happiness (2017) reminds us that happiness can be something else: 'Yet for more that two decades we have seen gusts of radical energy regularly breaking into 'the windless present' with their joyful moments of collective optimism, elation and sense of agency', and Hemmings talks of the 'dogged optimism' that sustains feminism (2011).
} 


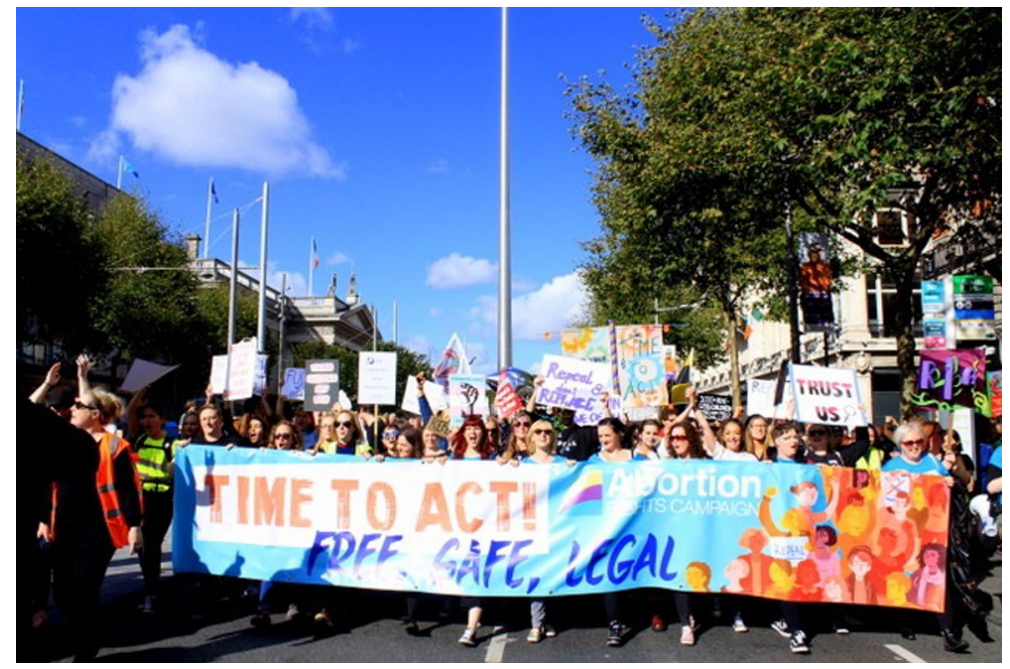

Fig. 1 The Abortion Rights Campaign lead the annual March for Choice in Dublin on the 30th September 2017

women and pregnant people for their ability to contribute to the reproduction of life. But we have also had the joy of watching \#RepealThe8th ${ }^{4}$ grow across generations and towns, stories and events (Fig. 1). Speaking of I.M.E.L.D.A.'s Knickers for Choice ${ }^{5}$ and Tara Flynn's Riding for Ireland ${ }^{6}$ are among the many happy moments that stand out for this repealer, as Irish feminism generated public power by working through the pain and into the pleasure. Figuring out the 'maybe' of \#RepealThe8th, will take many tellings, and much like the movement which holds the maybe in place, that figuring needs time to breathe. But as everyone gets on with life-demanding better, healing wounds, and translating travesty-let me use the space that Feminist Legal Studies provides to share some reflections on the significance of \#RepealedThe8th.

\section{Translating Travesty}

Dubliners have appropriated the monument in their midst through a multiple re-naming game, manifestly pleasurable, which reverberates with plurality of significations, often contradictory (but 'dreams go by contraries') infinitely translating travesty (Smyth 1989, 10).

\footnotetext{
4 The hashtag \#RepealThe8th became \#RepealedThe8th after the referendum. While I'm reflecting on the significance of having \#RepealedThe8th, there are times when I use \#RepealThe8th, the form that was contemporaneous with the campaign in the build up to the referendum.

5 See https://www.speakingofimelda.org/knickers-for-choice, NicGhabhann (2018), and Speaking of I.M.E.L.D.A. (2015).

${ }^{6}$ Riding for Ireland is the song that Tara Flynn performs as she closes her one woman show Not a Funny Word; see http://www.taraflynn.ie/about/ and http://thisispopbaby.com/shows/not-funny-word/. Accessed 27 August 2018.
} 
In 'Floozie in the Jacuzzi', Smyth captures a sense of translation as a popular, plural and pleasurable practice. She explains the multiple renaming strategies deployed by Dubliners as they poke fun at Anna Livia Plurabelle, the stone water feature that was a gift from the Smurfit Corporation which Dublin City Council placed right in the middle of O'Connell Street, one of the city's main thoroughfares, before she was moved on to other pastures. For Smyth these renaming strategies are the translation work of a post-colonial patriarchal culture as they provide a wealth of wordy nuggets, as they turn Anna Livia-the corporate gift to the municipal state with a nod to James Joyce-into something else: into a source of laughter, warmth and sustenance. But Smyth also voices an anxiety at the 'treacherous ambivalent power' of such translations when they do not change the paradigms for their own exercise and especially when they use Woman as the means of translation. Smyth herself as former academic (1992, 1993; McAuliffe 2002), longtime feminist and LGBT activist, founding member of Marriage Equality, co-ordinator of the Coalition to Repeal the Eighth, ${ }^{7}$ and co-director of Together for Yes, has been part of the process by which such translations have become audible in Ireland as womanly practices.

What would it mean to take such a socio-legal practice of translation as a starting point, a touchstone, for orienting critical appraisal of \#RepealThe8th and its afterlife? As Erdman says, legal boundary objects such as abortion are 'shared across multiple social worlds, and [assume] different meaning in each of these worlds' $(2017,30)$. To enable travel between these social worlds, I think we need a socially generated form of translation, which allows us to see the social content of legal forms as they move and multiply. If we start to think about the significance of repeal with a legal form, such as human rights, in hand, something pulls us towards the abstractions of legal institutions. But if we start with a social form like Smyth's translation, a form which is generated from the everyday practices of turning an inflated, pompous gift into a deflated, disempowered joke, then we might be better able to see the mutuality and multiplicity involved as legal objects, like the Eighth Amendment and its repeal, cross, and are part of social worlds.

Socio-legal translation in this sense could address concerns such as those expressed by Pierson and Bloomer (2017). They caution, on the basis of their study of rights discourse in Northern Ireland, that starting with a global vernacular of human rights risks not being transformative enough in its translation of reproductive harms into claims for legal change. Drawing on Merry's account of rights vernacularization (Merry 2006; Levitt and Merry 2009), they find that local Northern Irish use of the global vernacular has channelled media discourse towards the most 'deserving' and heart-breaking of cases at the expense of engaging more with broader autonomy and justice-based arguments. Similarly, De Londras and Markicevic $(2018,92)$ argue that engagement with 'first principles' arguments matters to the public, and that rights work needs to take its lead from ordinary public concerns.

Rizwan is among those who have responded to this kind of critique of rights translation, by arguing for 'mutual vernacularisation' (2017; see also Reilly 2011).

\footnotetext{
7 For more information on the campaign see: http://www.repealeight.ie; Accessed 26 June 2018.
} 
This kind of legal translation is not the hierarchical change which occurs as the local learns from the global. Rather for Rizwan, rights translation can be a process of mutual vernacularisation where 'the local also has the opportunity to transform the global.' It is precisely the complex, layered relationships between the local and the global, the particular and the general, that we need to analyse if we are better to understand how change comes about through socio-legal translations (see further Madhok 2018; Urquiza-Has 2017). A social form of translation such as that inspired by Smyth speaks to these concerns.

There were many translations at stake, as the social movement that was \#RepealThe8th became the official Together for Yes campaign. Could the campaign which had come to hold over 100 groups together since the days of the failure of the Protection of Life During Pregnancy Act (PLDPA), ${ }^{8}$ turn itself into a political force capable of winning a referendum? Could a big constitutional change build from a collection of micro-actions at the local level? How would the global scale of this possible constitutional change matter? Colleagues in other jurisdictions made clear that a successful repeal was also going to be significant for them in challenging their local restrictive laws. ${ }^{9}$ Media of all kinds from Facebook to the church pulpit made clear that conservative forces also thought it was significant. ${ }^{10}$ And even if \#RepealThe8th did happen, how would we translate that legal change into a fully fleshed out free, safe and local abortion service and all that would signify for meaningful respect for the reproduction of life? How does the collection of practical human activities not become absorbed by the travesty they're translating? Answering these questions will require many tellings of the \#RepealThe8th story. But finding and following the 'repeal energy' that drove this particular translation of the constitution into being, as it moved between social worlds might provide some clues.

The fundraiser that became so much more than a fundraiser ${ }^{11}$ was one key indication that repeal energy had indeed moved into Together for Yes, the official civic

\footnotetext{
8 This was the legislation that was adopted in 2013, 21 years after the Supreme Court criticized the Legislature for its failure to legislate and its mistreatment of pregnant women in life-threatening circumstances: Attorney General v X [1992] 1 IR 1, and 30 years after the Eighth Amendment had been adopted. But the PLDPA only implemented the decision in $A G v X$ by permitting abortion if and when medical practitioners said a woman's life, as distinct from her health, was at 'real and substantial risk'. While many of us supported the adoption of the legislation on the grounds that it at least provided a process for life-saving abortion, it was clear that there was a deep malaise that this miserable piece of legislation was all that had been achieved after 30 years of struggle; see further Murray (2016), Taylor (2015), Quilty et al. (2015) and Fletcher (2014).

${ }^{9}$ Personal communication with Paola Bergallo and Veronica Undurraga.

${ }^{10}$ In 2016, anti-abortion campaigner, Independent Senator Ronan Mullen, is heard encouraging US viewers to donate to Cherish Life Ireland on News Nightly, in a video clip which circulated widely during the campaign, available here https://www.youtube.com/watch?v=MW_YbBHjoks. He says: 'our little battle, we're a small country, but what happens here, for good or ill, will effect what happens in America, and elsewhere. Good news in Ireland will be good news abroad...' Accessed 15 September 2018.

11 See 'Together for Yes raise 400,000 in 3 days in crowdfunding campaign', Spunout.ie 13 April 2018, available here https://spunout.ie/news/article/together-for-yes-raise-400000-in-3-days-in-crowdfundingcampaign and 'Together for Yes campaign is on course to raise 500,000' The Irish Times 9 April 2018, available here https://www.irishtimes.com/news/ireland/irish-news/together-for-yes-campaign-says-it-ison-course-to-raise-500-000-1.3455596. Accessed 27 August 2018.
} 


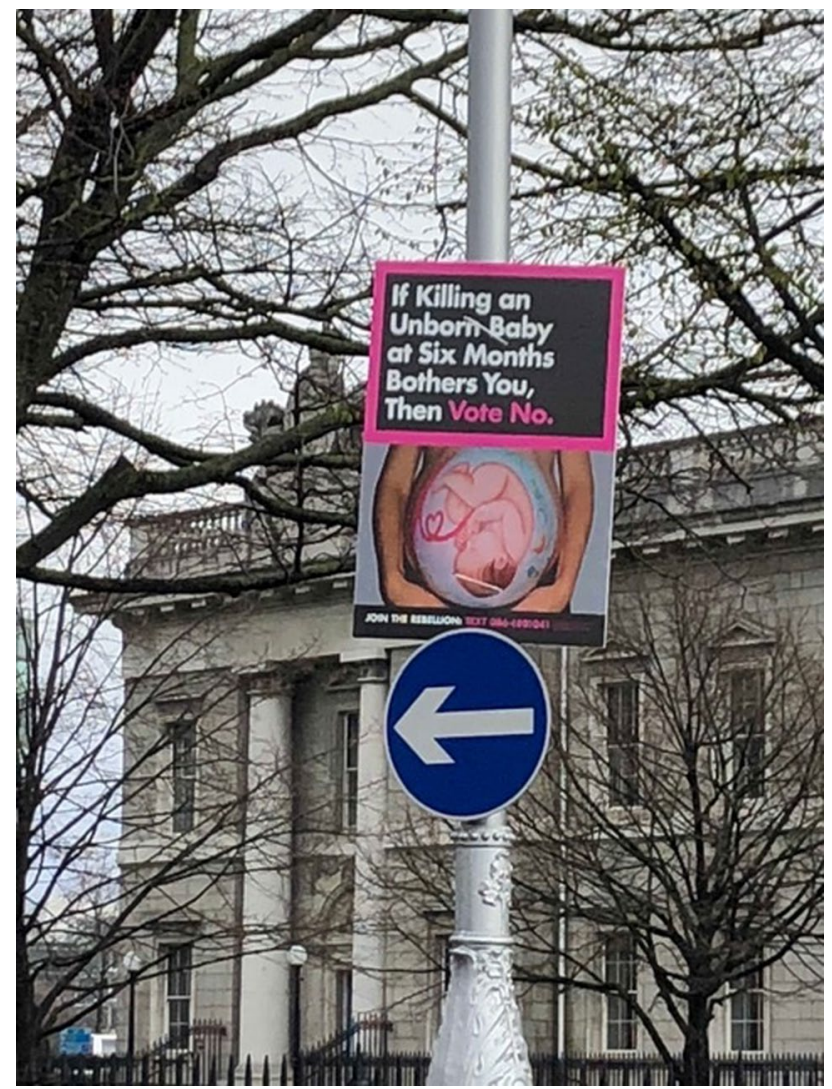

Fig. 2 A poster for the No campaign in the Irish abortion referendum, Customs House, Dublin, May 2018

campaign. The No posters in all their shaming glory had been up for a while. Somehow the No campaign - led by Save the Eighth ${ }^{12}$ and Love Both ${ }^{13}$ — had to hand the kind of resources that turned out glossy pictures of babies in wombs on streets from Clare to Wicklow, from Sligo to Cork (Figs. 2, 3). Although the political parties did campaign and distribute posters and leaflets, the civic society campaign was clearly the leader. ${ }^{14}$ TfY launched a crowdfunding campaign with the aim of raising

\footnotetext{
12 See their campaign website here https://www.save8.ie. Accessed 27 August 2018.

13 See their campaign website here: https://loveboth.ie. Accessed 27 August 2018.

14 De Londras and Markicevic note that Fine Gael, the party who were in government and introduced the Bill for the referendum, were neither pro-choice, nor pro-referendum, before the Citizens Assembly adopted recommendations supporting a move towards on request abortion provision $(2018,89)$. Fine Gael, a centre right party that currently forms the minority government under the leadership of Taoiseach (Prime Minister) Leo Varadker, appointed Josepha Madigan a government minister, to lead those party members who supported repeal in the campaign.
} 


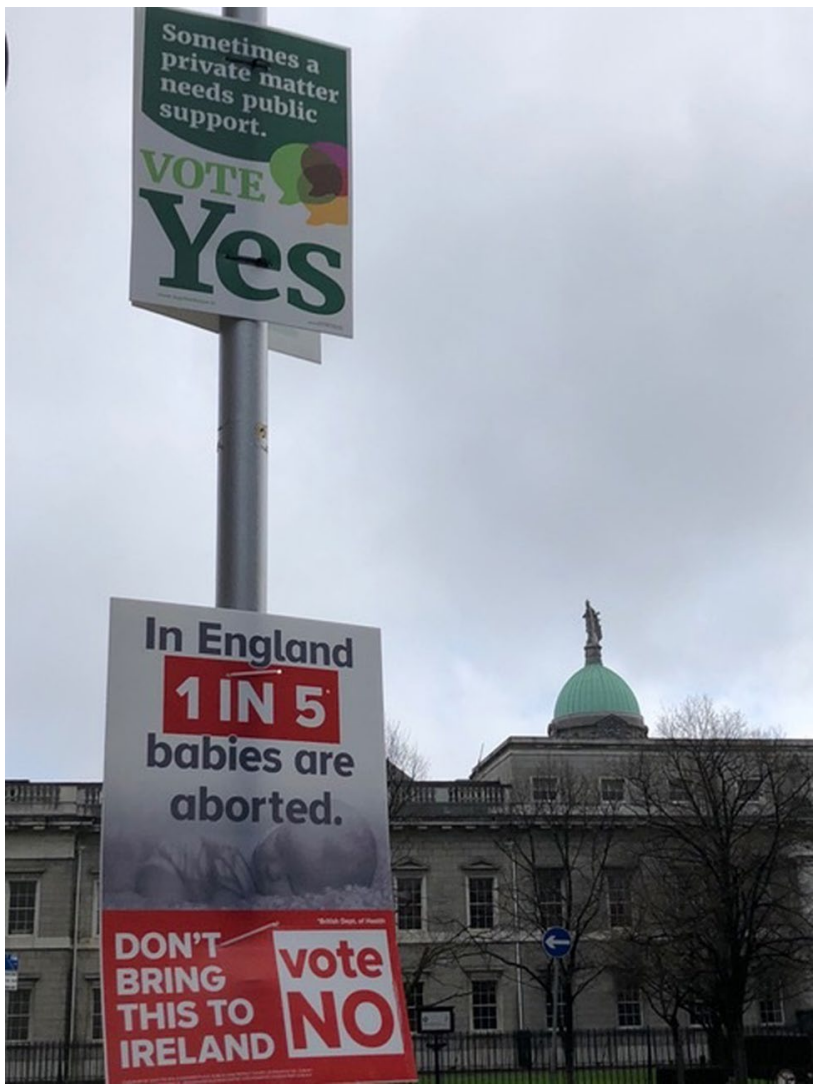

Fig. 3 Posters for the Yes and No campaigns in the Irish Abortion referendum, Customs House, Dublin, May 2018

$€ 50,000$ in seven days in order to buy posters. ${ }^{15}$ They raised the $€ 50,000$ in two hours, and went on to receive over $€ 500,000$ in donations of 2, 3, 5 euros, and their multiples, by the time the week had passed.

The donors left moving messages, messages that galvanized as they broke hearts and raised spirits in unequal measure. Reading them, tears pouring down my face, left me in little doubt that this moment was different. Almost everyone knew someone who had been humiliated by the travesty of the Eighth and the life-shrinking trail of which it was part. Almost everyone carried some sense that women in their lives had been done wrong and were due so much better. In a thread of tweets, Cara Sanquest, a Together for Yes volunteer organiser working on the crowdfunder, quoted Amanda Mellet's comment on her donation: 'In memory of Aoife, my

\footnotetext{
${ }^{15}$ See 'Over $250 \mathrm{k}$ in $12 \mathrm{~h}$ : Fundraising for Eighth Amendment campaigns takes centre stage' The Journal. 10 April 2018, available here: https://www.thejournal.ie/fundraising-eighth-amendment-39501 13-Apr2018/.
} 
beautiful baby girl who had a FFA, and for all the women who should never have to 'travel' whatever their circumstances' (@ caraquest 11 April 2018). ${ }^{16}$ Mellet's comment crystallises so much of what was significant about \#RepealThe8th, the generosity and openness to others that turned one person's suffering into a commitment that no-one else, not just those with the worst experiences, should be denied care at home. That everyday knowledge translated a fundraiser into that feeling, the one that's hard to put your finger on, but is 'worth its weight in gold' (Camplin and Scott 2015,325 ) in capturing the mobilising energy of human commitment to socio-legal change.

\section{Wanting Beautiful Experiments}

Esther Brown never pulled a soapbox onto the corner of 135th Street and Lenox Avenue to make a speech about autonomy, the global reach of the color line, involuntary servitude, free motherhood, or the promise of a future world, but she well understood that the desire to move as she wanted was nothing short of treason (Hartman 2018, 466).

There were also moments of beautiful, wayward experiments in the campaign as cries from the heart, like the cries from Esther Brown and the 'colored girls enclosed in the ghetto' (Hartman 2018, 470), translated other related painful experiences of gendered life into support for repeal. \#HomeToVote ${ }^{17}$ enacted a history of depletion through migration at the same time as it put a migrant-focused solidarity to work. The history of Irish emigration has been sanitized by the state in avoiding public responsibility for its own inability to provide (Lloyd 2013; Gilmartin 2015; Rossiter 2009). The celebration of Ireland's status as a 'global nursery' through the representation of emigration as a contribution to global relations is another example of the callous disregard for the labour that is the reproduction of life (MacLaughlin 1994). As migrants returned home to vote or to canvass, and as others provided mutual aid in contributing to the cost of their fares, this festering sore became a rallying cry, a demand for legal listening.

The possibility that this form of migrant solidarity could morph into a broader anti-racist politics to challenge the violence perpetrated against migrant bodies

\footnotetext{
16 Amanda Mellet, together with her husband James Burke, had to travel to the UK for an abortion in 2011 after she received a diagnosis of anencephaly in an Irish hospital and was not given any option of care there other than waiting to miscarry or deliver. She is a founding member of Termination for Medical Reasons http://fmrireland.com, who campaign for and provide information and support for others in similar situations. With the support of the Centre for Reproductive Rights, Mellet took a successful case to the United Nations Human Rights Committee where Ireland was found to be in breach of the right to freedom from cruel, inhuman and degrading treatment (Art 7 ICCPR) and the right to non-discrimination (Art 26 ICCPR); see UNHRC Decision CCPR/C/116/D/2324/2013, 9 June 2016; available at https:// www.reproductiverights.org/case/mellet-v-ireland and De Londras (2016).

17 As the London Irish Abortion Rights Campaign explain in their video and advice about how to participate, \#HomeToVote was first mobilized in the Marriage Equality referendum in 2015, see here https $: / / w w w . y o u t u b e . c o m / w a t c h ? v=c w \_y l r O L \_70$ and here https://hometovote.com. The size of the $66.4 \%$ majority in favour of repeal was such that \#HomeToVote was unlikely to have been a decisive factor, but it was important for other reasons (Hamill 2018; see also Sanquest 2017).
} 
hovered in the air. ${ }^{18}$ But an uglier undercurrent swirled around the returnees at times too. Repeal and its different mobilizations had moments of drawing on a postcolonial, rather than decolonial, desire to differentiate and develop, to become civilized and civilizing. ${ }^{19}$ The challenges of mounting a feminist campaign of constitutional reclamation while 'leaving no-one behind' seemed to ripple through the movement, come up against some stubborn resistance, and generate cries of anguish and anger. There was no doubt but that \#RepealThe8th was mobilized by a commitment to address the uneven effects of abortion restrictions and the devaluation of reproduction on racialised bodies and all those more vulnerable to law's violence. But the struggles over the roles of brown bodies, particularly migrant and Traveller bodies, in articulating the meaning of \#RepealThe8th were evident (MERJ 2018; Butterly 2018; Billings and Govi 2018; Lentin 2015) and became more painful as referendum day approached.

The outpouring of discontent over the death of Savita Halappanavar in a Galway hospital in October 2012 is well recognized as one of the critical moments in building public support for \#RepealThe8th (McCarthy 2016; Taylor 2015) (Fig. 4). ${ }^{20}$ Ms Halappanavar's death from sepsis and poor miscarriage management (HSE 2013) triggered a performance of public mourning that promised to convert the unconverted to \#RepealThe8th. The shame at the mistreatment of this young professional immigrant mother-to-be, whose request for an abortion was denied on the grounds that her foetus was still alive if unviable, and her grieving husband continues to reverberate. Hurt over the damage to other brown lives, particularly those of Ms C before Ms Halappanavar, and Ms Y after her, was also significant in the campaign for repeal (Butterly 2018; Fletcher 2005, 2014). But Halappanavar's death seemed to open a devastating gap which public mourning filled. There is too much to say about the role of mourning in \#RepealThe8th and how grief $^{21}$ generated repeal energy, even as it shared space with, and fed, a joyful, pleasure-seeking energy. But for now, let me note the cry of anguish that could be heard over the troubling way in which a brown woman's dead body became a site for repeal grief, when brown women's lives were not visibly front and centre in \#Together4Yes. Emily Waszak of Migrants and Ethnic Minorities

\footnotetext{
18 On the identification of the stranger as 'one of our own here', see Brah (1999) and Jones et al. (2017).

19 On some occasions, repeal arguments drew on a desire for Ireland to be more 'First World' in its approach to abortion, and differentiate itself from those uncivilized parts of the world where women died as a result of unsafe and restricted abortion; for earlier incarnations of this trend, see Fletcher (2001). This current of public discourse connected with the ugly racist politics that had accompanied another referendum on issues of reproductive politics in 2004, as the public voted for removal of birthright citizenship from those born on the island of Ireland who did not have Irish parentage; see further Harrington (2005).

20 You can watch passers-by at one of the Savita memorials comment on the significance of the referendum result in a video posted with this piece by Kitty Holland https://www.irishtimes.com/news/socia 1-affairs/savita-halappanavar-s-parents-really-really-happy-after-abortion-vote-1.3509839; see also https ://www.nytimes.com/2018/05/27/world/europe/savita-halappanavar-ireland-abortion.html. Accessed 27 August 2018.

21 The members of Termination for Medical Reasons played a significant role as they shared their grief over pregnancies lost to fatal foetal anomalies over and over again in the media and at public and private meetings up and down the country.
} 


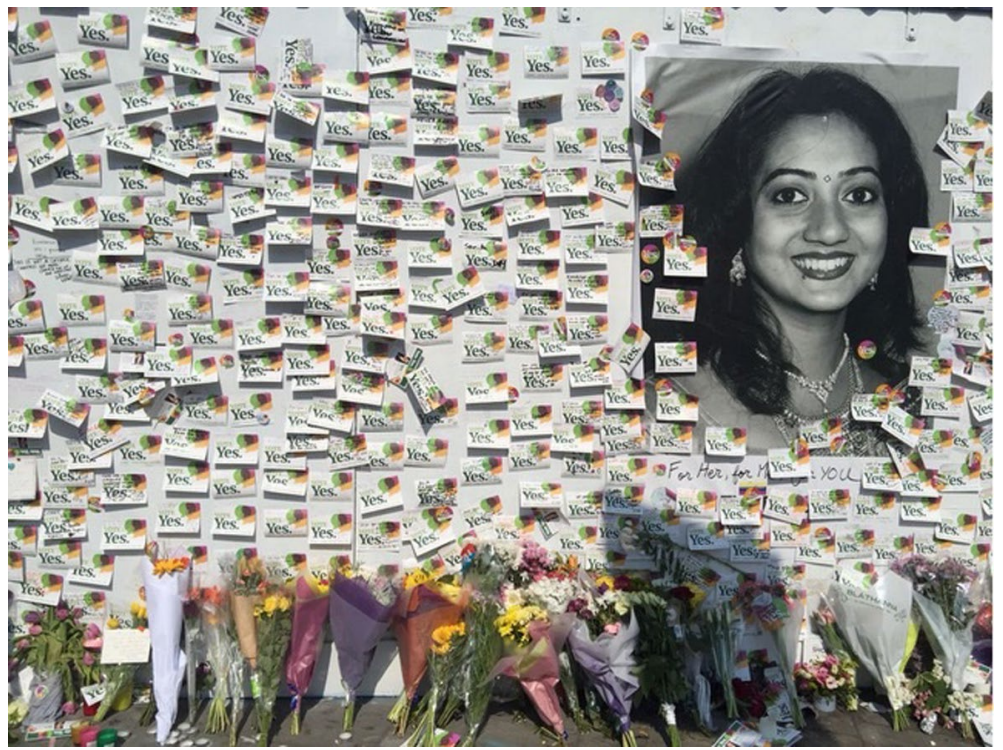

Fig. 4 A memorial to Savita Halappanavar covered in Together For Yes notes, Dublin, May 2018

for Reproductive Justice (MERJ) captured that cry of discomfort so well when she tweeted: 'I love the Savita memorial for so many reasons, but it is also a visceral reminder - the physical manifestation of white tears covering over an image of a brown migrant woman and her pain.' (@ waszaaaaak 30 May 2018).

Surely we can translate public grief over the necropolitics ${ }^{22}$ of Halappanavar's death into a call for centring repropolitics and valuing the reproduction of life, much like the Mexican feminists are doing. Gago talks about how the Women's Strike in Mexico responded to a need 'to mourn for those bodies that only come into our vision as a sequence of cadavers surrounded by horror' (2018, 661; see also Gutierrez Aguilar and Mason-Deese 2018). As reproductive health care advocates AIMS and migrant justice group MERJ point out, migrant women are disproportionately affected by poor medical care in pregnancy (De Vere 2018). For them, the Eighth was a problem not just because of abortion restrictions, but because it contributed to a culture of disrespecting women's, particularly migrant and ethnic minority women's, voices in maternity care. The decision by Together for Yes to focus on abortion, and not other ways in which the Eighth Amendment had a negative impact on reproductive rights, was seen as a marginalisation of minority ethnic women's concerns. Through the acts of MERJ, ${ }^{23}$ MASI, the Movement of Asylum Seekers

\footnotetext{
22 On necropolitics as the exercise of sovereign power over mortality, and who may live and who may die, see Mbembe (2003), Posocco et al. (2014).

23 MERJ held a public event on 12th May, sharing members, knowledge of abortion laws and conscientious objection (Fig. 4, and regularly participate in public events on reproductive justice and abortion rights, see MERJ 2018).
} 


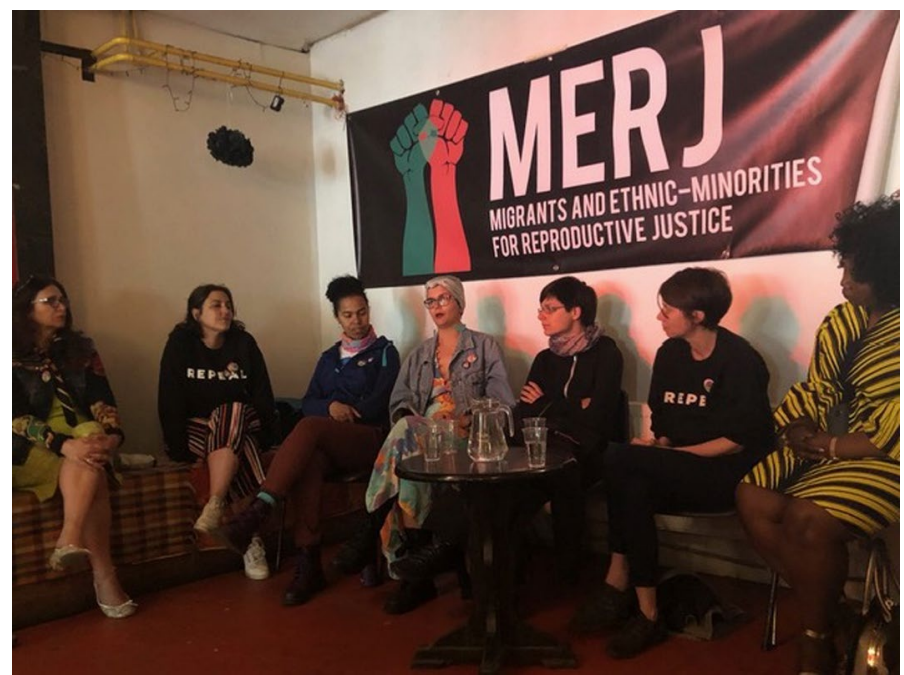

Fig. 5 Members of MERJ lead discussion of abortion laws and conscientious objection, Dublin, 12 May 2018

in Ireland, and their allies, the mourning of Savita could yet become 'an anarchy of coloured girls gathered together in a riotous manner'. In such a break with the order of things we might plant the 'ruin-seeds' (De Sousa Santos 2017, 258) of the Eighth Amendment, water a little, then watch a little, as we figure out how best to grow reproductive justice (Figs. 4, 5).

\section{Sharing Law}

In the process of becoming a legal expert, La Mesa consulted not only traditional experts and health providers but also women whose rights had been violated. This knowledge became the source of La Mesa's expertise and its opportunity to structurally change the battle over abortion (González Vélez and Jaramillo 2017, 111)

What might it mean to think more about law as a common resource that we share in our spaces of struggle? Legal actors such as advice clinics and human rights NGOs have a long tradition of opening up legal expertise in Ireland and elsewhere (O’Morain 2003; FLAC 2018; Bakhru 2017; Santos 2018; Krishnadas 2018; Levitt and Merry 2009). They challenge the professional enclosures performed by the big law firms and court infrastructure in order to make law more accessible and provide resources against brute power. When 'mere survival' is an achievement for so many (Hartman 2018, 470), sharing legal knowledge is one key means of making life better and of constituting a responsive socio-legal world. Colleagues in Latin America are among those who have built on this social tradition to engage in a form of public interest lawyering that retains a commitment to specialist expertise contributing to 
the movement for social justice in communicating that expertise (for a Spanish language example see Bergallo et al. 2018). But there are other ways in which the object of legal sharing may become closed and inaccessible even when being deployed for the participation and benefit of others (see further Rooney 2017). Open translation and mutual vernacularisation may be impeded by failures to locate sources of legal knowledge outside of the professional and technical. La Mesa articulate this problem, and a way of resolving it, when they explain why and how they generate legal expertise from women's experiences of rights violations (González Vélez and Jaramillo 2017; see also Lemaitre and Sandvik 2014; Santos 2018)

Feminist and other critical work on legal reform (Smart 1989; Hunter 2008) has long taught us that formal legal changes, even those like \#RepealThe8th which have been hard fought and won, do not in themselves achieve social change, and may not even achieve substantive legal change. The old ways of doing things are difficult to root out because they are matters of habit and institutionalization. ${ }^{24}$ We know that the legal ideology of gendered restrictions like the Eighth is a weed, which threatens to pop up all over the place in the new garden that we have worked so hard to clean up. This is why it so important not to reduce \#RepealThe8th to a formal legal result, which has been offered up by legal institutions who have seen the error of their ways. Rather the legal promise of \#RepealThe8th lies in the ways it captured a social yearning (hooks 1990) for sustained legal change. Figuring out repeal will mean working with and on this legal form as a socio-legal entanglement, so that we do not lose the value of law as a shared social resource.

One of the few advantages of having had to do this legal reform through the means of a referendum is that there has been extensive public engagement. Media research indicated high public confidence in understanding of the referendum issues. ${ }^{25}$ Challenges clearly remain in order to bed down the constitutional change and ensure meaningful agency-respecting and equitable access to abortion. But the experience of public engagement and the network of local groups are two key resources, which could feed the process of translating \#RepealThe8th into an actual agency-respecting abortion service and an ongoing practice of legal engagement and justice-seeking. While the kind of intense, accelerated campaigning involved in repeal is too exhausting to be sustainable, it is clear that there is significant potential to work with the experience of this network at different everyday paces in keeping law accountable to and informed by social experience.

But one of the ironies of the Together for Yes phase of the referendum campaign, whose narrativisation I don't yet understand, was its apparent view of legal expertise. A feminist campaign for constitutional reclamation seemed to treat 'legal expertise' as if it was a bounded technical object, which could not be repurposed by

\footnotetext{
${ }^{24}$ In Enright et al. (2018) and Fletcher et al. (2018) we draw attention to ways in which the proposed abortion legislation does not break enough with modes of legal thinking associated with the Eighth Amendment e.g. through over-criminalization and barriers to access.

25 Thirty-Sixth Amendment tot the Constitution Exit Poll, 25 May 2018, RTE and Behaviour and Attitudes Exit Poll https://static.rasset.ie/documents/news/2018/05/rte-exit-poll-final-11pm.pdf.
} 
feminism, and needed to be left to one side. Although lawyers ${ }^{26}$ were very present in Together for Yes-at local launches and national press briefings, as advisors, members and key role-players - there was a clear strategy not to rely on lawyers as spokespeople and not to make 'law' central to the case for repeal. Rather the key messages of the campaign focused on change, care and compassion through the use of personal stories and medical expertise. As a result, significant sources of legal expertise were not deployed, or were deployed outside the official campaign, or deployed inside the campaign but in a generic and traditional way.

Given the dominant public understanding of lawyers as either fat cats or technocrats, this is understandable at one level. But it did leave a significant gap in campaign discourse about the proper role of law, and signifies arguably a failure to come to grips, yet, with the broader significance of feminist and other critical ways of knowing and doing law. In seemingly taking the view that the campaign could not be legal and compassionate at the same time, it reproduced a technical and binary approach to law, played down its own assets in a history of social justice lawyering, and left the possibilities of a feminist affective legal approach untapped. ${ }^{27}$ But of course that did not stop other ways of doing law from surfacing and making themselves heard.

De Londras and Enright's work with About the Eighth ${ }^{28}$ and Repealing the Eighth (2018) provides clues in how better to address this gap. By performing legal knowledge as a public good, they showed how to displace the myth that critics cannot be 'objective explainers'. But they also showed how feminist modes of political persuasion could work through legal narrative, and that it was possible to mix both sets of activities, and do each well. At minimum, as Madhok says, this kind of legal education can draw attention to 'a differential distribution of citizenship characterised by judicial and political abandonment, including wilful ignorance of legal safeguards and instituted due process' $(2018,62)$. More maximally, their work pushes us along the path to answering what seems to me to be the more general challenge illustrated by \#RepealThe8th. How do we develop a process of socio-legal translation which combines specialist knowledge of law, a social network of educators and monitors (see Scott 2016), a living archive of material things, and people's experience of harmful conduct and wayward freedoms?

When Lawyers for Choice held an event at the Legal Eagle in Dublin, the main programming concern I had, was that the event should perform a kind of legal listening. ${ }^{29}$ As Dreher has explained (2009), the politics of listening is a way of taking the

\footnotetext{
${ }^{26}$ For example, Deirdre Duffy, the Campaign Manager, is a human rights lawyer who had previously worked as Deputy Director of the Irish Council of Civil Liberties. Peter Ward SC and Grainne Gilmour BL are barristers who acted as legal spokespeople for the campaign.

27 One example of an affectively invested critique as a way of life with law can be seen in the work of Otto whose conversation with Grear in featured in this issue (2018); see further: Hamzic (2017).

28 About the Eighth was a website-based resource which sought to answer questions about the law on abortion as it is, and as it was proposed to be; see https://aboutthe8th.com Accessed 27 August 2018.

29 Lawyers for Choice is a group of legal students, practitioners and academics who organise voluntarily to educate the public about abortion law and to promote reproductive justice; see Fig. 6 and their website at https://lawyers4choice.ie. Accessed 27 August 2018.
} 


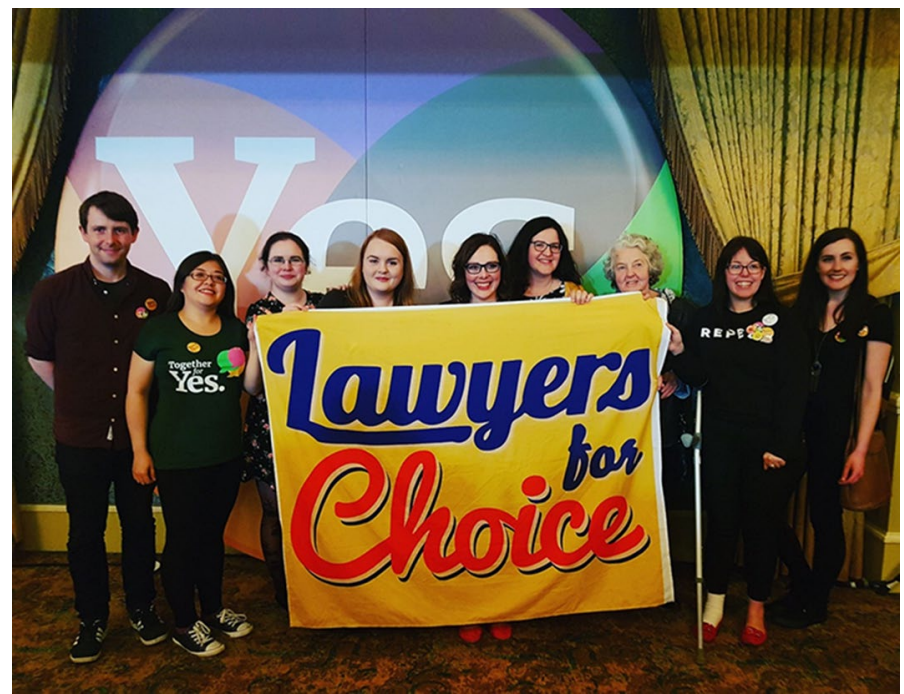

Fig. 6 Eoghan McMahon, Sophie Ryan, Sandra Duffy, Sinéad Williams, Katie Dawson, Sinéad Ring, Catherine Forde, Vicky Conway, and Ceile Varley, at the Together for Yes gathering on 26th May 2015, Dublin

responsibility for change away from the marginalized and instead focusing on the 'conventions, institutions and privileges which shape who and what can be heard', rather than on the politics of speech and representation (see also Urquiza-Has 2017). Bassel has also emphasised the importance of mutual listening in creating autonomous spaces where two or more groups generate new forms of intelligibility by listening to each other, rather than by asking the state for recognition (2017; see also Shalhoub-Kevorkian 2001). For her the politics of listening is about moving beyond an understanding of the multiplicity of public spheres to think more about the porosity between spheres and what we need to do to have a deeper exchange of experience of mutual learning between spheres.

As it happened, the event performed a mixture of speaking, representation and listening as the concern for filling out some gaps in the way legal knowledge had been shared was picked up by the speakers and chair, and took on a life of its own in the material space at the Legal Eagle on the 8th of May. ${ }^{30}$ The explicit purpose of the event was to launch a legal information leaflet, ${ }^{31}$ a collaboration between About the Eighth and Lawyers for Choice, which would complement the online sharing of information by providing a print version of key legal arguments for repeal. Catherine

\footnotetext{
30 Paula Geraghty, a photographer and filmmaker who has played a key role in recording social justice activities in Ireland over the years, filmed the presentations. You can see some of Geraghty's work here: https://vimeo.com/paulageraghty. Bernadette Ferguson and Romy O'Callaghan signed the presentations.

31 You can raad and download the leaflet here: https://lawyers4choice.files.wordpress.com/2018/05/4page-a5_v2.pdf and an easy read version here https://aboutthe8th.files.wordpress.com/2018/04/easyreadthe-8th-final-2.pdf. Accessed 12 October 2018.
} 
Forde, a feminist barrister who has been active on reproductive rights and social justice issues for a long time, including as an organiser during the Anti-Amendment Campaign in the 1980s, was frequently heard reminding other members of Lawyers for Choice of the important role of the physical bit of paper as a document linking strangers discussing repeal. The less explicit purpose, evident in the choice of speakers, was to draw on the circulating critical resources and address some of the exclusions and gaps that had occurred through sharing the law on the campaign trail.

We wanted to hold an event near the courts, lead with women's experience, displace the way that disability rights was being mobilized as an argument against repeal, and foreground the concerns of migrant and minority ethnic women. Amanda Mellet of Termination for Medical Reasons, ${ }^{32}$ who travelled for abortion care after a diagnosis of foetal anaecephaly and later took her case to the UN Human Rights Committee, held the legal audience in her hand as she explained law's devasting effects on her life and loves. Emma Burns, Ph.D. candidate at the Centre for Disability Law and Policy, and organiser with Tipperary for Choice, educated us in the different ways that disabled women and pregnant people were stigmatized and disadvantaged through legal abandonment on abortion. Natalia Fernandez of Migrants and Ethnic Minorities for Reproductive Justice, asked those present to consider the disproportionate impact of the failure to respect pregnant women's wishes on migrant and minority ethnic women. The lawyer, barrister and Lawyers for Choice steering group member Katie Dawson, was placed as the final speaker and enacted the possibility of legal responsiveness to personal experience and social expertise. Perhaps figuring out \#RepealThe8th could include a process where we make law a shared and enabling resource, one that grows from people's pains and pleasures as it finds a way to hold us together in mutual support.

\section{The Rest of Reproductive Life}

In much the same way that we reclaimed ownership of our bodies, so too is a movement where we seize back our basic, fully achievable right to homes and safe shelter the only way from here... We know they would not have listened to us then had we not risen up and made them. It's time to make them listen again (Redmond 2018a).

One of the challenges in our ongoing work to bring the best possible abortion care into being (Enright et al. 2018; Fletcher et al. 2018), is how to draw on the interdependence of the movement and connect up the practical work on implementation of \#RepealedThe8th with a broader feminist commitment to making the 'reproduction of life' central to politics. Feminists have long argued that the 'reproduction of life' includes, but is not just about having, and not having, babies (see further Bhattacharya 2017; Roberts 1997; Fletcher 2005). The practical activities that go into the sustenance of our communities and the generation of economic networks make up the

32 See http://tfmrireland.com. Accessed 12 October 2018. 
reproduction of life. Such activities generate value and embodied forms of property, contributions which are essential to capitalism and its need for replenished labour power, but are dressed up and taken from us as feminized and racialised 'gifts'.

The deficit of housing and shelter has been much on people's minds through and since the referendum. The willingness to blame mothers for the absence of a roof over children's heads expressed itself with force in the weeks that followed. Margaret Cash, a Traveller single mother of seven children, bravely called for public support as she drew people's attention to her reliance on the police station for shelter (O'Brien and Burns 2018) and was met with a torrent of racist and misogynist abuse. When feminists argue for the recognition and value of the unpaid activities which make sure children get fed, or bring people together to set up homes or occupy streets, they, we, are drawing attention to a reproductive economy of life, which needs direct and indirect sustenance.

This reproductive connection between abortion and everything that matters about life, has had, and continues to have, a visceral impact on social struggle in Ireland, struggles which seep over borders. As I write, the grief over the untimely death of a trans woman (Power 2018) being detained in a men's direct provision centre in Galway has been buried in the grief sweeping the country through the Pope's visit (Ryan 2018; on the link between trans justice and current abortion law reform see Duffy 2018). Having to tolerate the Pope visiting Ireland at the state's request and on the state's euro 4 months after the referendum was a trial for many. At one level the papal visit hurt because it represented the reassertion of a public power that has been eroded, an erosion to which \#RepealedThe8th testifies (O'Gorman 2018). But worse that than it was a reminder of the continuing failure of state and church to take meaningful action to address the harms to survivors and non-survivors of sexual and reproductive abuse, incarceration, forced adoption and disappearance (Enright 2018a; Gallen 2019; Gallen and Gleeson 2017; Ring 2017).

This failure pours salt into the wounds of those who are calling for openness, information and redress, as apologies such as that made by Kenny (2013), then Taoiseach (Irish Prime Minister), to the Magdalene women have not been translated into material goods such as meaningful access to healthcare and information about lost loved ones (Clann Project 2018; Justice for Magdalenes 2013; Gleeson 2017; O'Rourke 2011). Colm O'Gorman, a survivor of clerical sexual abuse, current director of Amnesty Ireland, founding member of One in Four, and key player in the Marriage Equality Referendum retold his story as he called for people to gather in the Garden of Remembrance at the time of the Papal Mass (O'Gorman 2018). Thousands of people gathered at \#Stand4Truth not to protest, but to use their physical presence to provide shelter for those who had suffered sexual abuse. They then walked silently to Sean McDermott Street, the site of the last state-owned Magdalene laundry which closed in 1996, and gave material form to the grief, anger, and solidarity that continues to haunt \#RepealThe8th and its afterlife.

\#Stand4Truth and other moments in the immediate afterlife of \#RepealedThe8th help us make sense of the incomplete reparations being done through repeal. They are intimately connected to earlier moments of reproductive injustice. The significance of repeal is almost unknowable without an appreciation for the lives lost and damaged along the way, without all the incomplete stories of the Mother and Baby 
Homes, the Magdalene laundries and the Industrial Schools. The stories of two individual women, Ann Lovett and Joanne Hayes, who had been the subjects of reproductive injustices 34 years previously (Maguire 2001) became particularly present as the campaign neared referendum day. They became part of the narrative of repeal as a form of restoration, as a means of valuing the rest of reproductive life.

Ann Lovett was a 15 year old girl who died alone near a grotto in rural Ireland, shortly after giving birth to her son who also died. On 5th May 2018, 20 days before the referendum, Rosita Boland published an interview with Ricky McDonnell, Ann Lovett's boyfriend of the time (Boland 2018). In this, his first public utterance, he shared a moving account of their relationship, how he learned of her death, and its impact on him afterwards. A few months previously, in January 2018, the Gardaí (police) made a public apology for the mistreatment of Joanne Hayes (Bohan 2018), a woman who had been wrongly accused of the murder of her baby in 1984, and subjected to 5 days of intrusive questioning during a tribunal which was supposed to be investigating Garda misconduct (see further Conway and Daly 2017; McCafferty 1985). The apology came as the decision to hold a referendum was being made and as the Oireachtas considered the recommendations of the Joint Oireachtas Committee on the Eighth Amendment.

Repeal, like the women's strike, is a process not an event (Gago 2018, 663). Its temporality cannot be, is not, reduced to the single date of 25th May 2018, or as Redmond says the 13 weeks of the 'official' campaign (2018b), or even the 35 years between the vote to adopt and the vote to repeal. The moment of repeal contains so many other moments, including those that were more proximate to the result itself. There was the moment when we heard the exit poll (Enright 2018b), the one where we watched the votes being counted, the one where we heard the result declared to the sounds of joyful, unrestricted tears and cheers, the one when the court cases ${ }^{33}$ ended, and a President, who had campaigned against the Eighth Amendment in 1983, signed the Thirty-Sixth Amendment Act into being.

While we think about the different moments captured by repeal and how they connect to the rest of reproductive life, we also need to think about replenishing repealers. How do we rest and restore ourselves as socio-legal participants at the same time as we seek the ongoing sustenance of reproductive life? One routine way that we do this is of course by gathering ourselves together whether at an activist workshop, academic conference or some other meeting place. One such opportunity came along in July 2018 as the Abortion and Reproductive Justice Conference was held in Makhanda, formerly Grahamstown, South Africa. ${ }^{34}$ This was the first conference I attended after repeal, and the conference itself has an interesting travelling history.

\footnotetext{
33 On 27th August, the Court of Appeal dismissed Joanna Jordan's challenge to the referendum saying that her claim that the electoral process had been abused was based on such flimsy evidence as to amount to an abuse of democratic process; see Jordan v Ireland and others [2018] IECA 291; available here http://www.courts.ie/Judgments.nsf/09859e7a3f34669680256ef3004a27de/f750d00ce4a6d807802582f60 04172f9? OpenDocument and for a related news report, see O'Faolain and Managh (2018).

34 The programme for the conference is available here: https://www.ru.ac.za/media/rhodesuniversity/ content/criticalstudiesinsexualitiesandreproduction/documents/20170717_TOPConference_SavetheDat esHires.pdf, and you can watch a South African news clip about the conference here: https://www.youtu be.com/watch?v=FY56CQYkJbY (SADC Digital News 10 July 2018). Accessed 14 November 2018.
} 


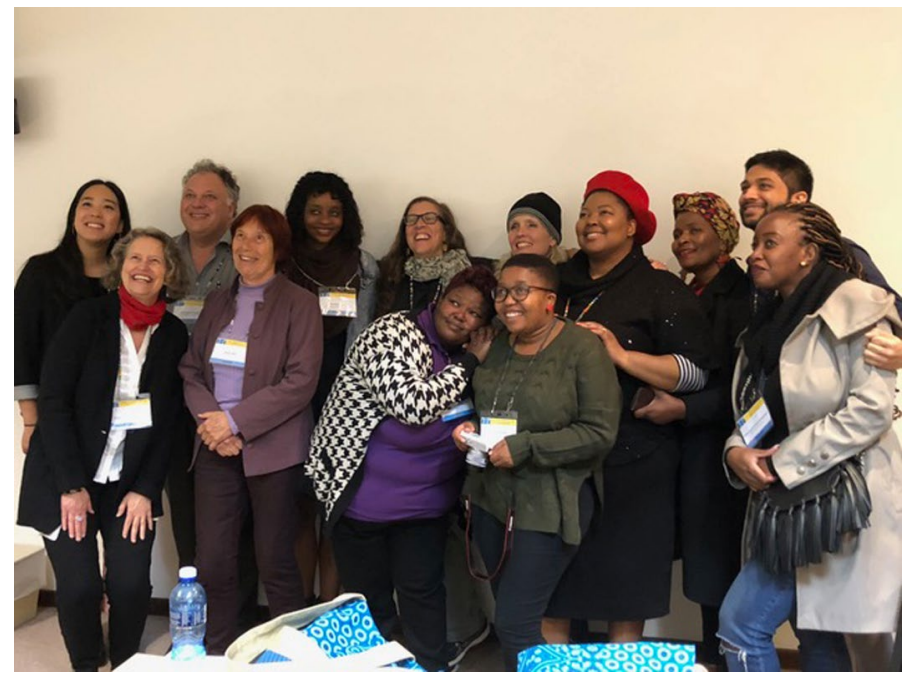

Fig. 7 Members of the Sexual and Reproductive Justice Coalition gathering at the Abortion and Reproductive Justice III Conference, Rhodes University, Makhanda, South Africa, July 2018

The first one was held in Prince Edward Island, Canada and the second one was held in Belfast, Northern Ireland (MacQuarrie et al. 2018; Bloomer et al. 2018). ${ }^{35}$ So, as well as being a wonderful occasion to connect with the work of scholars and activists from all over, it was also the first point of connection for some of us that had been involved in Repeal but hadn't seen each other since the days of the campaign.

When Michi Hyams of the Abortion Rights Campaign ${ }^{36}$ spoke from the audience at the opening plenary and identified herself as an Irish abortion activist, the audience burst into spontaneous joyful applause. That uplifting moment was followed by a few more. When the Sexual and Reproductive Justice Coalition ${ }^{37}$ held a roundtable and talked about how they had come into being, it was one of the most moving conference experiences I've ever had. They seemed tired and worn out by local and global challenges as the effects of local obstructions and global gag rules made their work difficult. But as I watched sex worker and youth activists, health care practitioners and even a government official reflect together on how they fought to get sexual pleasure as well as sexual rights and health on the agenda, I was so touched by their performance of collective sustenance (Fig. 7).

\footnotetext{
35 The programme for Abortion and Reproductive Justice II: An Unfinished Revolution is available here: http://www.raarn.ca/islandora/object/raarn\%3A1197, with a related news item here: http://www.irish news.com/news/2016/06/03/news/global-conference-on-abortion-being-held-in-belfast-544884/.

36 See https://www.abortionrightscampaign.ie.

37 See http://srjc.org.za.
} 


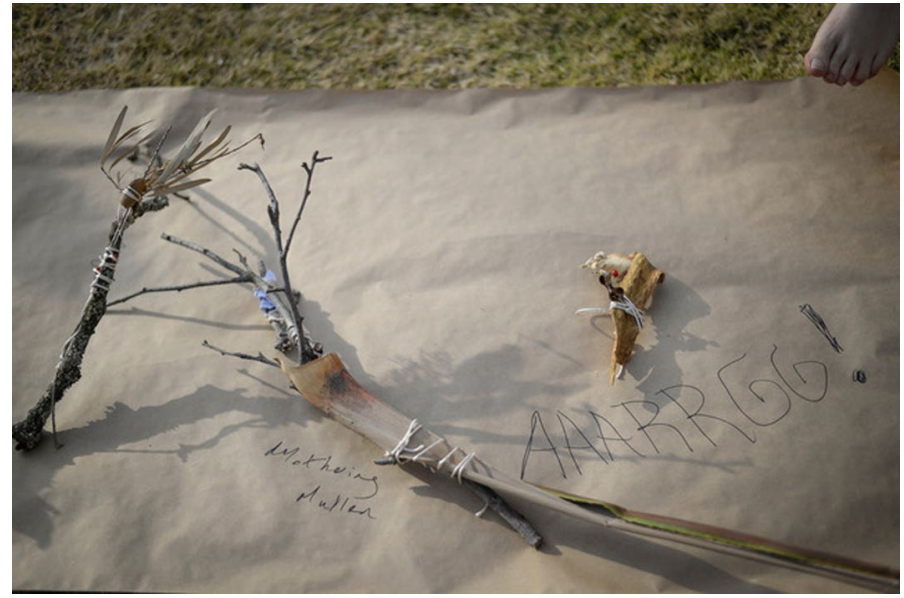

Fig. 8 Figures of Fury made by participants at the Abortion and Reproductive Justice III Conference, Makhanda, South Africa, July 2018

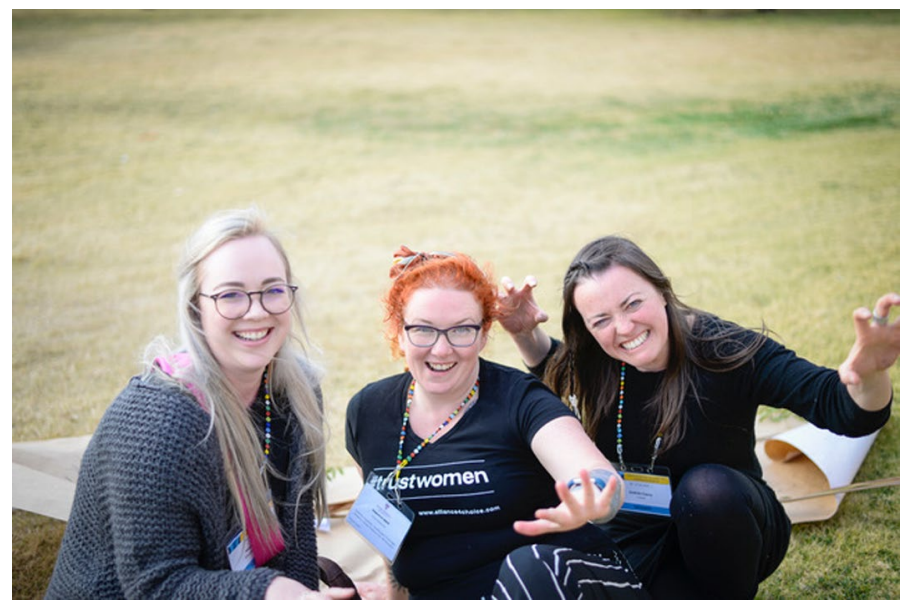

Fig. 9 Participants from the 'Furies' session, including Emma Campbell (centre) and Siobhan Clancy (right), Abortion and Reproductive Justice III, Makhanda, South Africa, July 2018

And then when Emma Campbell ${ }^{38}$ and Siobhan Clancy $^{39}$ led their session on 'Furies', ${ }^{40}$ it felt like they gave us the freedom to be (Figs. 8, 9). They gave us the

\footnotetext{
${ }^{38}$ You can find out more about Emma Campbell's work here https://www.emmacampbell.co.uk/artis tbio/.

39 You can find out more about Siobhan Clancy's work here https://www.facebook.com/Siobhán-Clanc y-100190236719498/.

${ }^{40}$ AD7: Furies, Monday 9 July 2018, Abortion and Reproductive Justice: The Unfinished Revolution III, Conference Programme, 51; Campbell and Clancy (2018); and see also https://www.emmacampbell.co. uk/furies/. Accessed 20 November 2018.
} 
freedom to be scholarly and practical, calm and outraged, performative and participatory, all at the same time. They draw on Marcus, Ahmed and others to think through anger, particularly as generated and communicated by survey responses and slogans from activists involved in repealthe8th. Their gift was attentive and futuristic in invoking the Furies, the Erinyes of Greek mythology that unwittingly carried obvious references to Irishness and yes votes, and transformed them from goddesses of vengeance to objects of feminist generation. And as they gave us this freedom, the making of a place where we could be ourselves in our apartness and in our togetherness, and various states in between, we gave them future furies. We made fury dolls out of twigs, leaves, string and paper, gave them names, and told stories of what bits of repeal, or equivalent, our fury dolls represented. These future furies circulated among us as a kind of 'thingified' energy that emerged from the stories and bodies that were there, and showed us how to stay going.

\section{Conclusion}

Repeal is not a legal strategy to be rolled out. Gago says of the Women's Strike 'it is anything but a calculated technique or a professional strategy' $(2018,661)$. Rather, as illustrated beautifully by Madonna of the Eyes, a banner made by Alice Maher, Rachel Fallon and Breda Mayock for the Artists for Repeal of the Eighth Amendment campaign, ${ }^{41}$ repeal was a kind of collective watchfulness. Repealers watched as we tried to figure out when, how and where to step in and hold each other up in the constitutional call to remove and replace the violence. As Godson explains in her analysis of the artists' banners, the repeat pattern of eyes across the Madonna's dress presents an alternative to the surveillance of the one Eye of Providence who sees all from Everywhere (2017). Instead the Madonna's many eyes refuse what Haraway calls the god trick of seeing everything from nowhere (1988), and invoke 'the watchful millions who observe the law-makers, the government and the oppressors' (Fig. 10).

This watchfulness opened up the vote, like feminists are doing with the strike, and helped generate a practice of compassionate voting. The observation was not a passive act, but a painful process of absorbing and appreciating the legal environment in order to make open, careful and knowing interventions about how a vote might be used. Repealthe8th is full of promise as a process of situated constitutionalism, which turned the observations of the watchful eyes not just into a result, but into an exchange over what legal participation might be.

Repeal in this decade of centenaries (McAuliffe and Gillis 2016), is different from the strike in using the less radical, and less spectacular, tool of the vote to withdraw our uteruses from the constitution-body-territory. But Repeal worked the

\footnotetext{
41 See figure 10 (as discussed in Godson (2017); see also Mia Mullarkey's film of the Artists Campaign to Repeal the Eighth Procession from the Magdalen Laundry in Limerick for the opening of EVA International 2018, available here: https://vimeo.com/267972988?ref=em-share.
} 


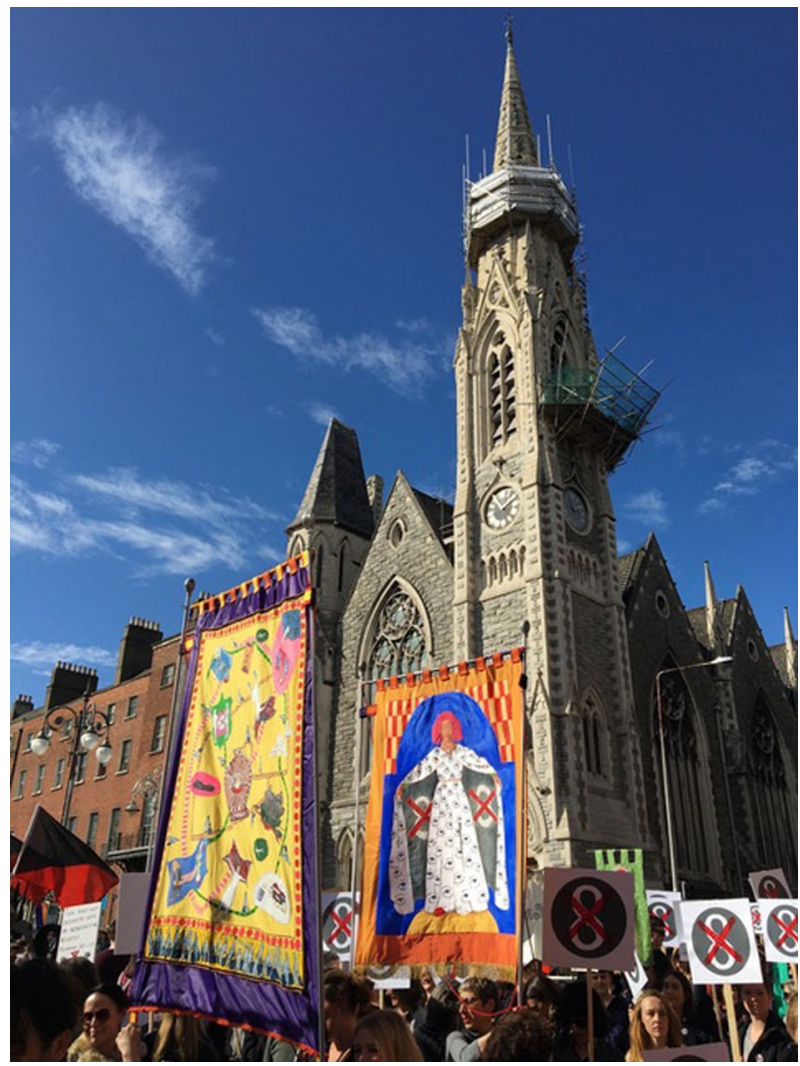

Fig. 10 'The Journeys' and 'Madonna of the Eyes', banners made by Alice Maher, Rachel Fallon, and Breda Mayock for the Artists' Campaign to Repeal the Eighth Amendment on the March for Choice on 30th September 2017 (photo credit Christian Kerskens)

tool of the vote alongside others, including marches, ${ }^{42}$ litigation, ${ }^{43}$ and independent service provision, ${ }^{44}$ to make the reproduction of life more of a voluntary and valued activity, even if that transition is incomplete in significant ways. It remains to be

\footnotetext{
${ }^{42}$ ARC's March for Choice has been held every year since 2012, in a bold gesture of feminist routinisation which saw the Irish abortion rights march move from being a responsive act, in reaction to the awful moments such as the X case in 1992, towards a more forward-oriented claiming of public space. In the run up the referendum campaign, \#IBelieveHer marches in support of the victim giving evidence in what became known as the Belfast rape trial, were also very present; see Hughes (2018).

${ }^{43}$ The Centre for Reproductive Rights played a key role in supporting Siobhan Whelan and Amanda Mellet in bringing their cases to the UN Human Rights Committee; see https://www.reproductiverights. $\mathrm{org} / \mathrm{press}-\mathrm{room} / \mathrm{un}$-committee-criminalization-of-abortion-in-ireland-violates-womans-human-rights-0. The Irish Family Planning Association played a key role in supporting the three women, A, B, and C, who took Ireland to the European Court of Human Rights; see https://www.ifpa.ie/advocacy/abortion-inireland-legal-timeline/. More generally see Yamin and Gloppen (2011).

${ }^{44}$ See Enright and Cloatre (2018) in this issue for a fascinating account of the role of the Irish Family Planning Association in challenging the legal restrictions of condom provision.
} 
seen how successful repeal will be as a means of broader socio-legal transformation and revaluing of life's reproduction more generally. Will the removal-by-vote of our uteruses from the constitution-body-territory contribute to the meaningful revaluing of reproductive contributions and redress for reproductive coercion? Could we open up repeal to make it cover other kinds of popularly informed legal calls on the state to remove the violence of sexual and reproductive discipline, and replace it with the pleasure of sexual and reproductive connection, connections which make space for the one body as it is joined with all bodies.

Repeal is a process of socio-legal translation which resulted in a vote for a feminist constitutional change. Repeal cannot be reduced to the vote itself, rather it made political subjects of those who have been 'maimed and humiliated' (Enright 2018b) by the Eighth. Our pain would not be reduced to a victimhood that left us in need of repair by medicine and the state. No, repeal would see us reclaim our very constitution, in law, in body, and in territory, as we asked others to vote with us. Repeal made the impossible possible as moments of conversation, together with their silent pauses, at kitchen tables, information stalls, street platforms and media studios, assembled somehow and turned a deceptively simple 'yes' out of a mess of collective joy, heart-breaking stories, legal exchange and reproductive connections.

Acknowledgements Writing this editorial has come at the end of my time as Lead Editor for Feminist Legal Studies, and I want to thank my colleagues on the Editorial Board, and everyone who has contributed to the journal's life, for making it such a rewarding experience. I'm so pleased to announce that Yvette Russell will be the new Lead Editor, and look forward to working with her in that role. Particular thanks to Julie McCandless, Sheelagh McGuinness, Fiona de Londras and Máiréad Enright for comments on an earlier version of this editorial.

\section{References}

Ahmed, Sara. 2010. The Promise of Happiness. Durham, NC: Duke University Press.

Bakhru, Tanya Saroj. 2017. Reproductive health and human rights: Lessons from Ireland. Journal of International Women's Studies 18(2): 27-44. https://vc.bridgew.edu/jiws/vol18/iss2/2/.

Bassel, Leah. 2017. The Politics of Listening: Possibilities and Challenges to Democratic Life. London: Palgrave Macmillan.

Berlant, Lauren. 2011. Cruel Optimism. Durham, NC: Duke University Press.

Bergallo, Paola, Isabel Christina Jaramillo Sierra, and Juan Marco Vaggione. 2018. El Aborto en America Latina. Beunos Aires: Siglo Veintiuno Editores Argentina S.A. Available at: https://www.redal as.net.

Bhattacharya, Tithi (ed.). 2017. Social Reproduction Theory: Remapping Class, Recentring Oppression. London: Pluto.

Billings, Jimmy, and Vedanth Govi. 2018. Savita's Law: The racial politics of repeal. The New Pretender. 28 June; Available at: http://new-pretender.com/2018/06/28/ireland-savitas-law-the-racial-politicsof-repeal/.

Bohan, Christina. 2018. After 34 years Gardaí have apologized to Joanne Hayes over the Kerry Babies Case. The Journal. 16 January. https:/www.thejournal.ie/kerry-babies-cahersiveen-investigationcold-case-3799545-Jan2018/.

Boland, Rosita. 2018. 'I was Ann Lovett's boyfriend'. The Irish Times. 5 May. https://www.irishtimes .com/life-and-style/people/i-was-ann-lovett-s-boyfriend-1.3484311.

Bloomer, Fiona, Claire Pierson, and Sylvia Estrada Claudio. 2018. Reimagining Global Abortion Politics: A Social Justice Perspective. Bristol: Policy Press.

Brah, Avtar. 1999. The scent of memory: Strangers, our own, and others. Feminist Review 61: 4-26. 
Butterly, Luke. 2018. Racism and reproductive health: Migrant rights and the Irish abortion referendum. Verso Books Blog 21 May; available here: https://www.versobooks.com/blogs/3840-racism-andreproductive-health-migrant-rights-and-the-irish-abortion-referendum.

Campbell, Emma, and Siobhán Clancy. 2018. Furies. Paper presented to Abortion and Reproductive Justice: The Unfinished Revolution III, 9 July (on file with the author).

Camplin, Hannah, and Emma Scott. 2015. 'We are a group of feminist lawyers doing what we can': An Interview with Emma Scott, Rights of Women. Feminist Legal Studies 23(3): 319-328.

Clann Project. 2018. Ireland's Unmarried Mothers and Their Children: Gathering the Data. Principal Submissions to the Commission of Investigation into Mother and Baby Homes. Dublin: Adoption Rights Alliance, Justice for Magdalenes Research and Hogan Lovells; Available at: http://clann project.org/clann-report/.

Conway, Vicky, and Yvonne Daly. 2017. The Report of the Tribunal of Inquiry into the Kerry Babies Case. In Northern/Irish Feminist Judgments: Judges' Troubles and the Gendered Politics of Identity ed. Máiréad Enright, Julie McCandless and Aoife O’Donoghue, pp. 195-218.

De Londras, Fiona. 2016. Fatal foetal abnormality, Irish constitutional law and Mellet v Ireland. Medical Law Review 24(4): 591-607.

De Londras, Fiona, and Máiréad Enright. 2018. Repealing the Eighth: Reforming Irish Abortion Law. Bristol: Policy Press. Available at: http://www.oapen.org/search?identifier=641853.

De Londras, Fiona, and Mima Markicevic. 2018. Reforming abortion law in Ireland: Reflections on the public submissions to the Citizens Assembly. Women's Studies International Forum 70: 89-98.

De Sousa Santos, Boaventura. 2017. The Resilience of Abyssal Exclusions in Our Societies: Toward a Post-Abyssal Law. Tilburg Law Review 22: 237-258.

De Vere, Taryn. 2018. 40\% of maternal deaths in Ireland are migrant and ethnic minority women. Her Family. Available here: https://www.herfamily.ie/pregnancy/40-of-maternal-deaths-in-ireland-aremigrant-women-293482.

Donohue, Katie. 2018. Meet the Radical Queers Fighting for LGBT + Rights in Ireland, Gay Community News 25 May. Available at: https://gcn.ie/meet-radical-queers-fighting-lgbt-rights-ireland/.

Dreher, Tanja. 2009. Listening across difference: Media and multiculturalism beyond the politics of voice. Continuum: Journal of Media and Cultural Studies 23(4): 445-458.

Duffy, Sandra. 2018. The Regulation of Termination of Pregnancies Bill - an argument for "pregnant people" wording. https://sandraduffy.wordpress.com/2018/07/18/the-regulation-of-termination-ofpregnancies-bill-2018-an-argument-for-pregnant-people-wording/. Accessed 27 August 2018.

Enright, Máiréad. 2018a. 'No. I won't go back': National Time, Trauma, and the Legacies of Symphysiotomy in Ireland. In Law and Time, ed. Sian Benyon-Jones and Emily Grabham. London: Routledge.

Enright, Máiréad. 2018b. The Labour of Legal Change: On the Final Days of the Irish Pro-choice Referendum. Critical Legal Thinking. 20 June. http://criticallegalthinking.com/2018/06/20/the-labou r-of-legal-change-on-the-final-days-of-the-irish-pro-choice-referendum/.

Enright, Máiréad, and Emilie Cloatre. 2018. Transformative Illegality: How Condoms 'Became Legal' in Ireland 1991-1993. Feminist Legal Studies. https://doi.org/10.1007/s10691-018-9392-1.

Enright, Máiréad, Vicky Conway, Fiona de Londras, Mary Donnelly, Ruth Fletcher, Natalie McDonnell, Sheelagh McGuinness, Natalie McDonnell, Claire Murray, and Sorcha ui Chonnactaigh. 2015. Abortion law in Ireland: A Model for Change. Feminists@Law 7(1). http://journals.kent.ac.uk/ index.php/feministsatlaw/article/view/173/631.

Enright, Máiréad, Ruth Fletcher, Fiona de Londras and Vicky Conway. 2018. Position Paper on The Updated General Scheme of the Health (Regulation of Termination of Pregnancy) Bill 2018. https ://lawyers4choice.files.wordpress.com/2018/08/position-paper-1.pdf.

Erdman, Joanna. 2017. Theorising Time in Abortion Law and Human Rights. Health and Human Rights 19(1): 29-40; https://www.hhrjournal.org/2017/06/theorizing-time-in-abortion-law-and-human-rights/.

FLAC. 2018. Lydia Foy and the Struggle for Transgender Rights in Ireland. Dublin: Free Legal Advice Centres. Available at: https://www.flac.ie/publications/lydia-foy-and-the-struggle-for-transgender-rights/.

FLAG. 1998. Reproductive control: A condition of women's equality and freedom. Ireland: Submission to the Interdepartmental Working Group on Abortion, Department of Health.

Fletcher, Ruth. 2001. Postcolonial Fragments: Representations of abortion in Irish law and society. Journal of Law and Society 28(4): 568-589.

Fletcher, Ruth. 2005. Reproducing Irishness: Race, gender and abortion law. Canadian Journal of Women and the Law 17(2): 365-404.

Fletcher, Ruth. 2014. Contesting the cruel treatment of abortion seeking women. Reproductive Health Matters 22(44): 10-21. 
Fletcher, Ruth, Sheelagh McGuinness, Vicky Conway, Fiona de Londras, and Máiréad Enright. 2018. Briefing paper on the Health (Regulation of Termination of Pregnancy) Bill 2018. 23 October. https://lawyers4choice.files.wordpress.com/2018/10/hrtop_briefing_final.pdf.

Gago, Verónica. 2018. \#WeStrike: Notes towards a political theory of the feminist strike. South Atlantic Quarterly 117(3): 660-670.

Gallen, James. 2019. Redressing gendered mistreatment: Magdalen laundries, symphisiotomy and the mother and baby homes. In Gender and the Law in Modern Ireland, ed. Lynsey Black and Peter Dunne. Dublin: Hart.

Gallen, James, and Kate Gleeson. 2017. Unpaid wages: The experiences of Irish magdalene laundries and indigenous Australians. International Journal of Law in Context 14(1): 43-60.

Gilmartin, Mary. 2015. Ireland and migration in the twenty first century. Manchester: Manchester University Press.

Gleeson, Kate. 2017. A woman's work is... unfinished business: Justice for the disappeared Magdalen women of modern Ireland. Feminist Legal Studies 25(3): 291-312.

Godson, Lisa. 2017. Solemn and Bedazzling. Visual Artists Ireland 31 October. https://visualartistsir eland.com/solemn-and-bedazzling. Accessed 27 November 2018.

González Vélez, Ana Cristina, and Jaramillo Isabel Cristina. 2017. Legal knowledge as a tool for social change. Health and Human Rights Journal 19(1): 109-118. Available here: https://www.hhrjournal .org/2017/06/legal-knowledge-as-a-tool-for-social-change-la-mesa-por-la-vida-y-la-salud-de-lasmujeres-as-an-expert-on-colombian-abortion-law/.

Gutierrez Aguilar, Rachel, and Liz Mason-Deese. 2018. Women's struggle against all violence in Mexico: Gathering fragments to find meaning. South Atlantic Quarterly 117(3): 670-681; available at: https://doi-org.ezproxy.library.qmul.ac.uk/10.1215/00382876-6942245.

Hamill, Aoife. 2018. One month on \#HomeToVote didn't change the result, but it did change the country. London Irish Abortion Rights Campaign Blog. 24 June; Available here https://londonirisharc. com/repeal-london/2018/6/26/one-month-on-hometovote-didnt-change-the-result-but-it-did-chang e-the-country.

Hamzic, Vanja. 2017. Affective critique: Fear, hope, abandonment and pleasure in Dianne Otto's living with international law. Feminists@Law 7(1). http://journals.kent.ac.uk/index.php/feministsatlaw/ article/view/399/993.

Haraway, Donna. 1988. Situated knowledges: The science question in feminism and the privilege of partial perspective. Feminist Studies 14(3): 575-599.

Harrington, John A. 2005. Citizenship and the biopolitics of post-nationalist Ireland. Journal of Law and Society 32(3): 424-449.

Hartman, Saidiya. 2018. The anarchy of colored girls assembled in a riotous manner. South Atlantic Quarterly 117(3): 465-490. https://doi.org/10.1215/00382876-6942093.

Hemmings, Clare. 2011. Why Stories Matter: The Political Grammar of Feminist Theory. Durham NC: Duke University Press.

HSE. 2013. Investigation of Incident 50278 from Time of Patient's Self Referral to Hospital on the 21st of October 2012 to the Patient's Death on the 28th of October, 2012 (the Arulkumaran Report 2013). Dublin: Health Services Executive. https://www.hse.ie/eng/services/news/media/pressrel/newsa rchive/2013archive/jun13/savitareport.html.

hooks, bel. 1990. Yearning: Race, Gender and Cultural Politics. Cambridge, MA: South End Press.

Hughes, Brendan. 2018. Rugby Rape Trial: 'I Believe Her' rallies planned across Ireland. Irish News. 29 March. http://www.irishnews.com/news/northernirelandnews/2018/03/29/news/rugby-rape-trial -i-believe-her-rallies-planned-across-ireland-1290667/.

Hunter, Rosemary. 2008. Domestic Violence Law Reform and Women's Experience in Court: The Implementation of Feminist Reforms in Civil Proceedings. New York: Cambria Press.

Jones, Hannah, Yasmin Gunaratnam, Gargi Bhattacharyya, William Davies, Sukhwant Dhaliwal, Kirsten Forkert, Emma Jackson, and Roiyah Saltus. 2017. Go Home? The Politics of Immigration Controversies. Manchester: Manchester University Press.

Justice for Magdalenes. 2013. Principal Submission to the Interdepartmental Committee to establish the facts of State Involvement in the Magdalen Laundries. http://www.magdalenelaundries.com/State _Involvement_in_the_Magdalene_Laundries_public.pdf.

Kenny, Enda. 2013. State apology to the Magdalene women. The Journal. 19 February. http://www.thejo urnal.ie/full-text-enda-kenny-magdalene-apology-801132-Feb2013/. 
Krishnadas, Jane. 2018. CLOCK: The 'Community Legal Companion' as an agent of change: A transformative methodology. In Reimagining Clinical Legal Education, ed. Linden Thomas, Stephen Vaughan, Bharat Malkani, and Theresa Lynch. London: Hart.

Lemaitre, Julieta, and Kristen Sandvik. 2014. Beyond sexual violence. Feminist Legal Studies 22(3): 243-261. https://doi.org/10.1007/s10691-014-9274-0.

Lentin, Ronit. 2015. After Savita: Migrant mothers and the politics of birth in Ireland. In The Abortion Papers Ireland, vol. 2, ed. Aideen Quilty, Sinéad Kennedy, and Catherine Conlon, 179-188. Cork: Cork University Press.

Levitt, Peggy, and Sally Merry. 2009. Vernacularization on the ground: Local uses of global women's rights in Peru, China, India and the United States. Global Networks: A Journal of Transnational Affairs 9(4): 441-461. https://doi.org/10.1111/j.1471-0374.2009.00263.x.

Lloyd, David. 2013. What's in a name? The Dialectics of Diaspora and Irish Emigration. Breac: A Digital Journal of Irish Studies, 12 April; Available here: https://breac.nd.edu/articles/whats-in-a-namethe-dialectics-of-diaspora-and-irish-emigration/.

MacLaughlin, Jim. 1994. Ireland: The Emigrant Nursery and the World Economy. Cork: Cork University Press.

MacQuarrie, Colleen, Fiona Bloomer, Claire Pierson, and Shannon Stettner (eds.). 2018. Crossing Troubled Waters: Abortion in Ireland, Northern Ireland and Prince Edward Island. Charlottetown: Island Studies Press.

Madhok, Sumi. 2018. Coloniality, political subjectivation and the gendered politics of protest in a 'state of exception'. Feminist Review 119(1): 56-71.

Maguire, Moira. 2001. The changing face of Catholic Ireland: Conservatism and liberalism in the Ann Lovett and Kerry Babies Scandals. Feminist Studies 27(2): 335-358.

Mbembe, Achille. 2003. Necropolitics. Public Culture 15(1): 11-40. https://doi.org/10.1215/08992 363-15-1-11.

McAuliffe, Mary. 2002. Interview with Ailbhe Smyth. Tall Girl Shorts. http://www.tallgirlshorts.net/ marymary/ailbhe.html.

McAuliffe, Mary, and Liz Gillis. 2016. Richmond Barracks 1916: We were there: 77 Women of the Easter Rising. Dublin: Dublin City Council.

McCafferty, Nell. 1985. A Woman to Blame: The Kerry Babies Case. Dublin: Attic Press.

McCarthy, Joan. 2016. Reproductive Justice in Ireland: A feminist analysis of the Neary and Halappanavar cases. In Ethical and Legal Challenges in Irish Healthcare, ed. Mary Donnelly and Claire Murray. Manchester: Manchester University Press.

McGuinness, Sheelagh. 2015. A guerrilla strategy for a pro-life England. Law, Innovation and Technology 7(2): 283-314.

Migrants and Ethnic-minorities for Reproductive Justice (MERJ), 2018. We've come a long way. Dublin: MERJ.

Merry, Sally Engle. 2006. Human Rights and Gender Violence: Translating International Law into Local Justice. Chicago: Chicago University Press.

Murray, Claire. 2016. The Protection of Life during Pregnancy Act 2013: Suicide, dignity and Irish discourse on abortion. Social and Legal Studies 25(6): 667-698.

NicGhabhann, Niamh. 2018. City walls, bathroom stalls and tweeting the Taoiseach: The aesthetics of protest and the campaign for abortion rights in the Republic of Ireland. Continuum: Journal of Media and Cultural Studies 32(5): 553-568.

O'Brien, Tim, and Sarah Burns. 2018. Homeless children spend night on chairs in Tallaght Garda Station. The Irish Times. 9 August. https://www.irishtimes.com/news/ireland/irish-news/homelesschildren-spend-night-on-chairs-in-tallaght-garda-station-1.3590748.

O'Faolain, Aodhain, and Ray Managh. 2018. 'Reckless' attempt to appeal abortion referendum result dismissed. The Irish Times. 27 August. https://www.irishtimes.com/news/crime-and-law/court s/reckless-attempt-to-appeal-abortion-referendum-result-dismissed-1.3608991 mode $=$ sampl e\&auth-failed $=1 \& \mathrm{pw}$-origin $=$ https $\% 3 \mathrm{~A} \% 2 \mathrm{~F} \% 2 \mathrm{Fwww}$.irishtimes.com $\% 2$ Fnews $\% 2 \mathrm{Fcrime}$-andlaw\%2Fcourts\%2Freckless-attempt-to-appeal-abortion-referendum-result-dismissed-1.3608991.

O'Gorman, Colm. 2018. 'I was 13 when the Pope came to Ireland and I was raped by a priest the next year'. The Journal. 4 August. https://www.thejournal.ie/readme/colm-ogorman-pope-rape-abuse -church-catholic-4169924-Aug2018/.

O'Morain, Padraig. 2003. Access to Justice for All: The History of FLAC 1969-2003. Dublin: FLAC https://www.flac.ie/publications/access-to-justice-for-all/. 
O'Rourke, Maeve. 2011. Ireland's Magdalene Laundries and the State's duty to protect. Hibernian Law Journal 10: 200-237.

Otto, Dianne, and Anna Grear. 2018. International law, social change, and resistance. Feminist Legal Studies. https://doi.org/10.1007/s10691-018-9393-0.

Pierson, Claire and Fiona Bloomer. 2017. Macro and micro political vernacularization of rights in Northern Ireland. Health and Human Rights Journal 19(1): 173-185. https://www.hhrjournal .org/2017/06/macro-and-micro-political-vernaculizations-of-rights-human-rights-and-abortiondiscourses-in-northern-ireland/.

Posocco, Silvia, Adi Kuntsman, and Jin Haritaworn (eds.). 2014. Queer Necropolitics. London: Routledge.

Power, Jack. 2018. Friends of trans woman who died in direct provision celebrate her life. The Irish Times. 4th August. https://www.irishtimes.com/news/social-affairs/friends-of-trans-woman-whodied-in-direct-provision-celebrate-her-life-1.3585923.

Quilty, Aideen, Catherine Conlon, and Sinéad Kinnedy (eds.). 2015. The Abortion Papers Ireland, Volume 2. Cork: Cork University Press.

Redmond, Sinéad. 2018a. 'No more than she deserves' Feminist Ire: Not Your Fluffy Feminism, 13 August. https://feministire.com/2018/08/13/no-more-than-she-deserves/.

Redmond, Sinéad. 2018b. It's been two months now. Feminist Ire: Not Your Fluffy Feminism, 27 July. https://feministire.com/2018/07/27/its-been-two-months-now/.

Reilly, Niamh. 2011. Doing transnational feminism, transforming human rights: The emancipatory possibilities revisited. Irish Journal of Sociology. 19(2): 60-76.

Ring, Sinéad. 2017. The victim of historical child sexual abuse in the Irish Courts 1999-2006. Social and Legal Studies. 26(5): 562-580.

Rizwan, Rakhshan. 2017. Local flows: The pleasure-centric turn in human rights advocacy in South Asia. Tilburg Law Review 22(1): 31-61. http://booksandjournals.brillonline.com/content/journ als/10.1163/22112596-02201003.

Roberts, Dorothy. 1997. Killing the black body: Race, reproduction and the meaning of liberty. Pantheon.

Rooney, Eilish. 2017. Justice learning in transition. Transitional Justice Institute Research Paper No. 18-02; Available at http://dx.doi.org/10.2139/ssrn.3051156.

Rossiter, Ann. 2009. Ireland's Hidden Diaspora: The abortion trail and the making of a London-Irish underground 1980-2000. London: IASC Publishing.

Ryan, Nicky. 2018. 'Stand For Truth' crowd marched in silence to remember abuse survivors as Papal Mass took place. The Journal, 26 August https://www.thejournal.ie/stand-for-truth-pope-franc is-4202944-Aug2018/.

Sanger, Carol. 2017. About abortion: Terminating pregnancy in twentieth first century America. Harvard: Harvard University Press.

Sanquest, Cara. 2017. 'When the fasten seatbelt light illuminates, my right to decide what happens to my body is paused'. The Journal, 19 March. https://www.thejournal.ie/readme/as-a-british-resident-ican-access-abortion-but-when-the-fasten-seatbelt-light-illuminates-my-right-to-decide-what-happe ns-to-my-body-is-paused-3289091-Mar2017/.

Santos, Cecilia MacDowell. 2018. Mobilizing women's human rights: What/whose knowledge counts for transnational legal mobilziation? Journal of Human Rights Practice 10(2): 191-211. https://doi. org/10.1093/jhuman/huy019.

Scott, Dayna. 2016. 'We are the Monitors now': Experiential knowledge, transcorporeality and environmental justice. Social and Legal Studies 25(3): 261-287.

Segal, Lynne. 2017. Radical Happiness: Moments of Collective Joy. London: Verso.

Shalhoub-Kevorkian, Nadera. 2001. Using the dialogue tent to break mental chains: Listening and being heard. Social Service Review 75(1): 135-150.

Smart, Carol. 1989. Feminism and the power of law. Oxford: Sage.

Smyth, Ailbhe. 1989. The Floozie in the Jacuzzi. Irish Studies Review 6: 7-24.

Smyth, Ailbhe. (ed.) 1992. The Abortion Papers Ireland. Dublin: Attic Press.

Smyth, Ailbhe. 1993. The 'X' Case: Women and abortion in the Republic of Ireland 1992. Feminist Legal Studies 1(2): 163-177. 
Speaking of I.M.E.L.D.A. 2015. Dirty work still to be done: Retrieving and activating feminist acts of resistance. Contemporary Theatre Review. http://www.contemporarytheatrereview.org/2015/marga retta-darcy/.

Taylor, Maeve. 2015. Women's right to health and Ireland's abortion laws. International Journal of Gynaecology and Obstetrics 130: 193-197.

Urquiza-Has, Nayeli. 2017. Mistranslating vulnerability: A defence for hearing. Tilburg Law Review 22: 5-30.

Yamin, Alicia Ely, and Siri Gloppen. 2011. Litigating health rights: Can Courts Bring More Justice to Health?, 2011. Cambridge, MA: Harvard University Press. 